\title{
Expression of Class II Transplantation Antigen on Vascular Smooth Muscle Cells in Human Atherosclerosis
}

\author{
Lena Jonasson, Jan Holm, Omar Skalli, Giulio Gabbiani, and Göran K. Hansson \\ Arterial Biology Group, Departments of Histology and Medicine I, University of Göteborg, Sweden; Department of Surgery I, \\ University of Göteborg, Sahlgrenska Hospital, Göteborg, Sweden; and Department of Pathology, University of Geneva, Switzerland
}

\begin{abstract}
A large proportion of the cells of the human atherosclerotic plaque is assumed to be derived from medial smooth muscle cells. In contrast to these, the cells of the plaque have the capacity to accumulate lipid, and they also proliferate at a higher rate than medial cells. It has therefore been suggested that smooth muscle cells undergo a change of phenotype during atherogenesis, but there has been no evidence for such a change on the molecular level. We have now analyzed carotid artery plaques using a battery of antibodies against cell surface and cytoskeletal antigens, and found that most of the cells express the class II transplantation antigen (Ia antigen) HLADR. Also, the beta chain of HLA-DR was detected by immunoblotting of plaque extracts with the OKIal monoclonal antibody. HLA-DR is normally present on cells of the immune system, but only $60 \%$ of the DR-positive cells of the plaque reacted with monoclonal antibodies specific for macrophages and lymphocytes. Many of the remaining DR-positive cells contained the muscle-specific intermediate filament protein, desmin. This indicates that smooth muscle cells of atherosclerotic plaques express DR antigen. In contrast, very few DRpositive cells were found in normal human arteries. This suggests that expression of class II antigen is part of a phenotypic change in smooth muscle cells in atherosclerosis.
\end{abstract}

\section{Introduction}

The major histocompatibility complex (MHC) ${ }^{1}$ encodes several groups of proteins. Among these, class I transplantation antigens (in humans, the HLA-ABC system) are expressed on almost all nucleated cells (1). In contrast, class II transplantation antigens (in humans, HLA-DR, HLA-DC, and HLA-SB, collectively often referred to as Ia antigens) are generally limited to cells involved in the immune system $(2,3)$. These glycoproteins, when present in the plasma membrane of macrophages, participate in the presentation of foreign antigens to $T$ cells $(2,4)$. Other cells, such as endothelial cells and Langerhans' cells of the skin, may also express class II antigen (5-12), and

Address correspondence to Dr. Hansson, Department of Histology, University of Göteborg, P.O. Box 33031, S-400 33 Göteborg, Sweden.

Received for publication 2 May 1984 and in revised form 21 February 1985.

1. Abbreviations used in this paper: FITC, fluorescein isothiocyanate; MHC, major histocompatibility complex; $M \mathrm{r}$, relative molecular weight; TBS, Tris-buffered saline.

J. Clin. Invest.

(c) The American Society for Clinical Investigation, Inc. 0021-9738/85/07/0125/07 \$1.00

Volume 76, July 1985, 125-131 they may also serve as antigen-presenting cells $(5,6,11)$. Finally, class II antigens can be expressed on several other cell types under certain conditions. Intestinal, urinary, and other epithelia may express class II antigens, as well as several tumor cells $(9,13-21)$. The functional significance of this phenomenon is unknown, although it has been suggested that these cells might also present antigens to $\mathrm{T}$ cells (22).

In this study, we have detected class II antigen on smooth muscle cells in human atherosclerotic plaques with the use of antibodies to HLA-DR. The majority of the cells in surgical biopsies of carotid artery plaques expressed HLA-DR antigen. Only $60 \%$ of the cells were positive for markers for macrophages or leukocytes. Among the remaining DR-positive cells, many had desmin-containing intermediate filaments, and could therefore be identified as smooth muscle cells (23-25). In contrast, no smooth muscle cells were HLA-DR positive in biopsies of normal human arteries. These data suggest that smooth muscle cells, which do not normally express class II antigens, are induced to express HLA-DR in atherosclerosis.

\section{Methods}

Arterial tissue. Atherosclerotic arterial biopsies were obtained from 16 patients with atherosclerosis of the internal carotid arteries. The patients were between 48 and $70 \mathrm{yr}$ old, and did not have any other systemic diseases. They were operated on due to cerebral manifestations, usually transitory ischemic attacks, and fibrofatty plaques were obtained during thromboendarterectomy. Nonatherosclerotic arterial biopsies were obtained from the aortic base during coronary bypass surgery, and from the uterine artery during hysterectomy. Coronary bypass patients $(n=5)$ were between 53 and $69 \mathrm{yr}$ old, and hysterectomy patients $(n=4)$ were between 26 and $48 \mathrm{yr}$ old. All biopsies were immersed in ice-cold Hanks' balanced salt solution (HBSS), were transported to the laboratory, and processed further within $20 \mathrm{~min}$ after the excision. Carotid arteries were also obtained at the autopsies of four patients (aged 30, 64, 65, and $87 \mathrm{yr}$ ). The arteries were removed within $36 \mathrm{~h}$ after death, and were analyzed by immunofluorescence of frozen sections.

Antibodies. The mouse monoclonal antibody OKIal, directed against human HLA-DR $(26,27)$, was obtained from Ortho Diagnostic Systems, Inc., Raritan, NJ, and the rat monoclonal YE2.36, also directed against the HLA-DR protein (28), was obtained from Seralab, Crawley Down, England. The mouse monoclonals anti-Leu-4, directed against a cell surface antigen on $T$ lymphocytes (29), and anti-LeuM3, directed against a surface antigen on monocytes and macrophages (30), were purchased from Becton-Dickinson \& Co., Oxnard, CA. DAKO-pan-B, a mouse monoclonal against a surface antigen on $B$ lymphocytes, was bought from Dako, Copenhagen, Denmark. Rabbit antibodies to human Factor VIII and rhodamine-labeled swine-antirabbit IgG were bought from Dako, and biotinylated horse-anti-mouse IgG, goat-anti-rabbit IgG, and rabbit-anti-rat IgG were obtained from Vector Laboratories, Burlingame, CA.

Rabbit antibodies to vimentin were raised in the following way. Vimentin was isolated from cultured bovine endothelial cells by preparative electrophoresis (31), and rabbits were immunized three 
times with Freund's incomplete adjuvant. A hyperimmune serum was obtained after a booster injection, and its specificity was tested by electroblotting and immunocytochemistry.

Antibodies to desmin were raised in rabbits immunized with chicken gizzard desmin (32). Specific antibodies were isolated from the antiserum by affinity chromatography as described (33).

Immunofluorescence. Parts of the specimens from all patients were embedded in OCT embedding medium (Miles Laboratories, Inc., Elkhart, IL) and snap-frozen in n-hexane that was chilled with liquid nitrogen. 8- $\mu \mathrm{m}$ sections were fixed for $5 \mathrm{~min}$ in $95 \%$ ethanol, rinsed in phosphate-buffered saline (PBS, $150 \mathrm{mM} \mathrm{NaCl}, 20 \mathrm{mM}$ phosphate buffer, $\mathrm{pH} 7.2$ ), and preincubated with $2 \%$ normal serum, immediately followed by incubations with either mouse or rat monoclonal antibodies or rabbit polyclonal antibodies, which were all diluted in PBS with 4\% bovine serum albumin (Sigma Chemical Co., St. Louis, MO). After being rinsed repeatedly with PBS, the sections were incubated in a similar fashion with biotinylated antibodies against mouse, rat, and rabbit IgG, respectively. They are then rinsed again, incubated with fluorescein isothiocyanate (FITC)-labeled avidin (Vector Laboratories) at $25 \mu \mathrm{g} / \mathrm{ml}$, rinsed, and mounted in PBS with $10 \%$ glycerol. The sections were examined in a fluorescence microscope (Ultraphot III; Carl Zeiss, Oberkochen, West Germany), equipped with an HBO50 lamp, epi-illumination, dielectric interference filters, and $20 \times$ and 40 $X$ fluorescence objectives. All antibodies were used at optimal dilutions determined by chessboard titrations. The following controls were performed: omission of $(a)$ the first or $(b)$ the second antibody, use of preimmune serum instead of $(c)$ first or $(d)$ second antibody, $(e)$ use of an unrelated antibody instead of first antibody, or $(f)$ use of an unrelated, biotinylated antibody instead of the second antibody.

A control for binding of the Fc part of specific antibodies to the Fc receptor of cells in the sections was made in the following way. Immune complexes were made by incubating human serum albumin with anti-albumin antibodies (Dako) at a molar ratio of $1: 1$, for $3 \mathrm{~h}$ at $37^{\circ} \mathrm{C}$. After being washed, they were diluted in PBS $(1: 2,1: 20$, and 1 : $200)$ and incubated on sections. The sections were then incubated with OKIa1, biotinylated anti-mouse IgG, and FITC-avidin.

The number of immunoreactive cells was determined in the following way. At a magnification of $200(20 \times$ objective $)$, eight microscopic fields were randomly chosen in the plaques. After counting, the sections were demounted and counterstained with Mayer's hemalun. Fields that had been counted were identified, and all nuclei were counted. Between 100 and 200 cells were present in each field.

In double-staining immunofluorescence experiments, sections were first incubated with a monoclonal antibody, followed by biotinylated anti-mouse IgG and FITC-avidin as described above. They were then exposed to rabbit-anti-Factor VIII, rabbit-anti-vimentin, or rabbit-antidesmin antibodies followed by rhodamine-conjugated swine-anti-rabbit IgG. In controls, either one or both of the primary antibodies were omitted or substituted by preimmune IgG.

Histochemistry. Fresh cryostat sections were incubated for $\mathbf{4 0} \mathrm{min}$ in a substrate solution for detection of alpha-naphtyl acetate esterase as described (34), and then counterstained with Mayer's hemalun.

Isolation of cells. Parts of the arterial biopsies were immediately cut into small pieces with fine forceps, washed twice in HBSS by lowspeed centrifugation, and digested for $60 \mathrm{~min}$ at $37^{\circ} \mathrm{C}$ on a shaking water bath with a modification of the method described by Haley et al. (35). Digestion was with $900 \mathrm{IU} / \mathrm{ml}$ collagenase (Cl. histolyticumcollagenase type I, Sigma Chemical Co.), $1.0 \mathrm{mg} / \mathrm{ml}$ soybean trypsin inhibitor (Sigma), and $5.0 \mathrm{mg} / \mathrm{ml}$ bovine serum albumin in calciumand magnesium-free HBSS. The digested material was filtered through a $150-\mu \mathrm{m}$ mesh nylon filter, and cells were harvested by low-speed centrifugation. They were washed twice with HBSS, and subjected to the receptor assays described below. All glassware used with the cells were siliconized.

$F c$ receptor assay. This assay was performed essentially as described by Bianco et al. (36). In brief, a washed concentrate of sheep erythrocytes was incubated with anti-sheep erythrocyte antiserum (Statens Bakteriologiska Laboratorium, Stockholm, Sweden) for $60 \mathrm{~min}$ at room temperature. The coated erythrocytes were washed twice with PBS and suspended to a concentration of $1 \% .500 \mu \mathrm{l}$ of a suspension of the isolated arterial cells $\left(10-20 \times 10^{4}\right.$ cells $\left./ \mathrm{ml}\right), 200 \mu \mathrm{l}$ fetal bovine serum (FBS, Flow Laboratories, Irvine, Scotland), and 10 drops of the erythrocyte suspension were mixed by centrifugation at $40 \mathrm{~g}$ for 5 min, and the loose pellet was incubated for $45 \mathrm{~min}$ at $37^{\circ} \mathrm{C}$. The cells were resuspended, and drops of cells were air-dried onto microscopic slides and fixed with ice-cold acetone. Cells were counterstained with $0.1 \%$ Evans blue in PBS to quench erythrocyte autofluorescence, and were then stained with OKIal using the biotin-avidin immunofluorescent system as described above.

$E$ receptor assay. $\mathrm{T}$ cell-specific $\mathrm{E}$ receptors (sheep erythrocyte receptors) were demonstrated as described (37). Briefly, AET-(32aminoethylisothiouronium-hydrobromide) treated sheep erythrocytes were suspended to a concentration of $10 \%$, and eight drops of this suspension were incubated for $5 \mathrm{~min}$ at $37^{\circ} \mathrm{C}$ with $500 \mu \mathrm{l}$ of a suspension of isolated arterial cells and $200 \mu \mathrm{l}$ FBS. The mixture was then centrifugated at $40 \mathrm{~g}$ for $5 \mathrm{~min}$, and incubated as a loose pellet at $+4^{\circ} \mathrm{C}$ overnight. The cells were resuspended, and HLA-DR-positive cells were detected with $\mathrm{OKIal}$ and biotin-avidin-immunofluorescence as described above.

Characterization of $H L A-D R$ expression. Isolated plaque cells were divided into four portions. One was immediately fixed with acetone and stained for HLA-DR as described. The second portion was treated for $30 \mathrm{~min}$ at $37^{\circ} \mathrm{C}$ with $5 \mathrm{mM}$ EDTA, $320 \mathrm{mM}$ sucrose, $5 \mathrm{mM}$ PBS, pH 7.4, to remove extrinsic plasma membrane proteins (38). After being washed in HBSS, the cells were analyzed for HLA-DR expression by immunofluorescence. The third portion of cells was incubated with $0.25 \%$ trypsin in PBS for $30 \mathrm{~min}$ at $37^{\circ} \mathrm{C}$, washed with HBSS with $20 \%$ FBS, and analyzed for HLA-DR. The fourth portion was also treated with trypsin as described and washed with FBS-containing HBSS, but then incubated for $3 \mathrm{~h}$ at $37^{\circ} \mathrm{C}$ in HBSS-FBS before staining for HLA-DR. Some of the slides from the latter group were doublestained for HLA-DR and desmin as described above.

Electrophoresis and immunoblotting. 5- $\mathrm{mm}^{3}$ pieces of human carotid artery atherosclerotic plaques were homogenized in SDS sample buffer (39) with a Polytron homogenizer, and the proteins were separated by SDS-polyacrylamide gel electrophoresis using a Laemmli system with a 10\% separating gel. Part of the gel was stained with Coomassie Brilliant Blue; the rest was used for electroblotting. Polypeptides were transferred to nitrocellulose paper at $60 \mathrm{~V}$ in a Tris-glycine buffer, $\mathrm{pH}$ 8.3 , with $20 \%$ methanol (40). One part of the paper was used for antibody incubations, and the other was stained with Amido black. For antibody staining, the paper was preincubated for $5 \mathrm{~h}$ with $0.3 \%$ gelatin in TBS (Tris-buffered saline, $150 \mathrm{mM} \mathrm{NaCl}, 10 \mathrm{mM}$ Tris- $\mathrm{HCl}$, pH 7.4), followed by an 8-h incubation with OKIal at 1:100 in TBSgelatin. After being rinsed, the paper was incubated for $6 \mathrm{~h}$ with ${ }^{125} \mathrm{I}$ labeled rabbit-anti-mouse IgG, rinsed again, and exposed to Kodak Xomat-AR film (Eastman Kodak Co., Rochester, NY) for $3 \mathrm{~d}$ at $-85^{\circ} \mathrm{C}$.

\section{Results}

Cell surface proteins were detected in human arterial tissue by immunofluorescence, using monoclonal antibodies to the cell surface protein, followed by biotinylated anti-mouse IgG and FITC-avidin. The class II transplantation antigen, HLA-DR, was detected with the monoclonal antibody OKIal, which reacts with a framework determinant common to all allelic forms of the human HLA-DR protein (26). In the carotid plaques, many DR-positive cells were found immediately beneath the endothelium, but others were distributed throughout the fibrous cap and in the necrotic core of the plaque (Figs. 1 and 2). 69\% of the cells in carotid atherosclerotic plaques contained HLA-DR antigen, and $37 \%$ of the cells in the nonatherosclerotic intima surrounding the plaque were HLA-DR positive (Table I). Similarly, $73 \%$ of the cells in aortic atherosclerotic plaques obtained at autopsy were DR- 


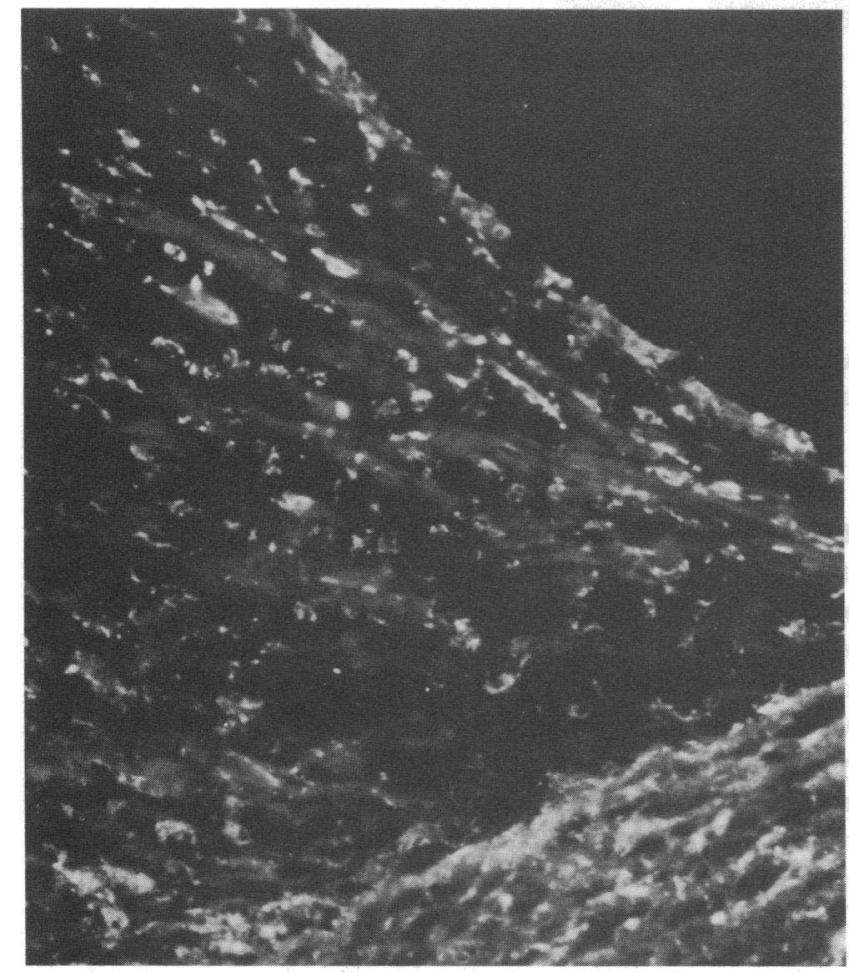

Figure 1. Immunofluorescent detection of HLA-DR antigen at the edge of an atherosclerotic plaque from the carotid artery. A large proportion of the cells is HLA-DR positive. In addition, there is a yellow autofluorescence at the base of the plaque (lower right hand corner) (magnification of 500). positive. In contrast, intima from nonatherosclerotic carotid arteries contained only 7\% DR-positive cells. Surgical biopsies of nonatherosclerotic aortas contained only $2 \%$ DR-positive cells, and biopsies of uterine arteries did not contain any DRpositive cells. (Fig. $3 A$ and $B$, Table I).

Standard immunofluorescent control experiments were all negative. In addition, the possibility of binding of antibodies to Fc receptors in the tissue was excluded by preincubation of sections with immune complexes. This did not affect the frequency of DR-positive cells (data not shown).

The HLA-DR antigen is known to be present on monocytes, macrophages, B lymphocytes, and certain T lymphocytes, and such cells were therefore identified in the vessel wall with monoclonal antibodies to cell type-specific antigens. In the carotid artery plaques, $29 \%$ of all cells were identified as monocyte/macrophages positive for the antibody Anti-LeuM3 (Table I). Their distribution and number corresponded to that of alpha-naphtyl acetate esterase-positive cells in parallel sections. The frequency of $T$ cells, as defined by the pan- $T$ cell antibody Anti-Leu-4, was $11 \%$, and $1 \%$ of all cells were stained by the B cell-specific antibody Dako-pan-B. Monocytes, macrophages, $B$ cells, and $T$ cells could therefore account for only a fraction of the DR positive cells in the plaques. The data suggest that $\sim 40 \%$ of the DR-positive cells of the plaque are not derived from the blood.

This conclusion was supported from studies of cells isolated from the plaques. As shown in Tables II and III, 60\% of these cells were HLA-DR positive. $30 \%$ of the cells also expressed Fc-receptors, which are present on monocytes, macrophages, granulocytes, and some lymphocytes $(41,42)$, and only $5 \%$ had $E$ rosettes characteristic of $T$ cells (37).

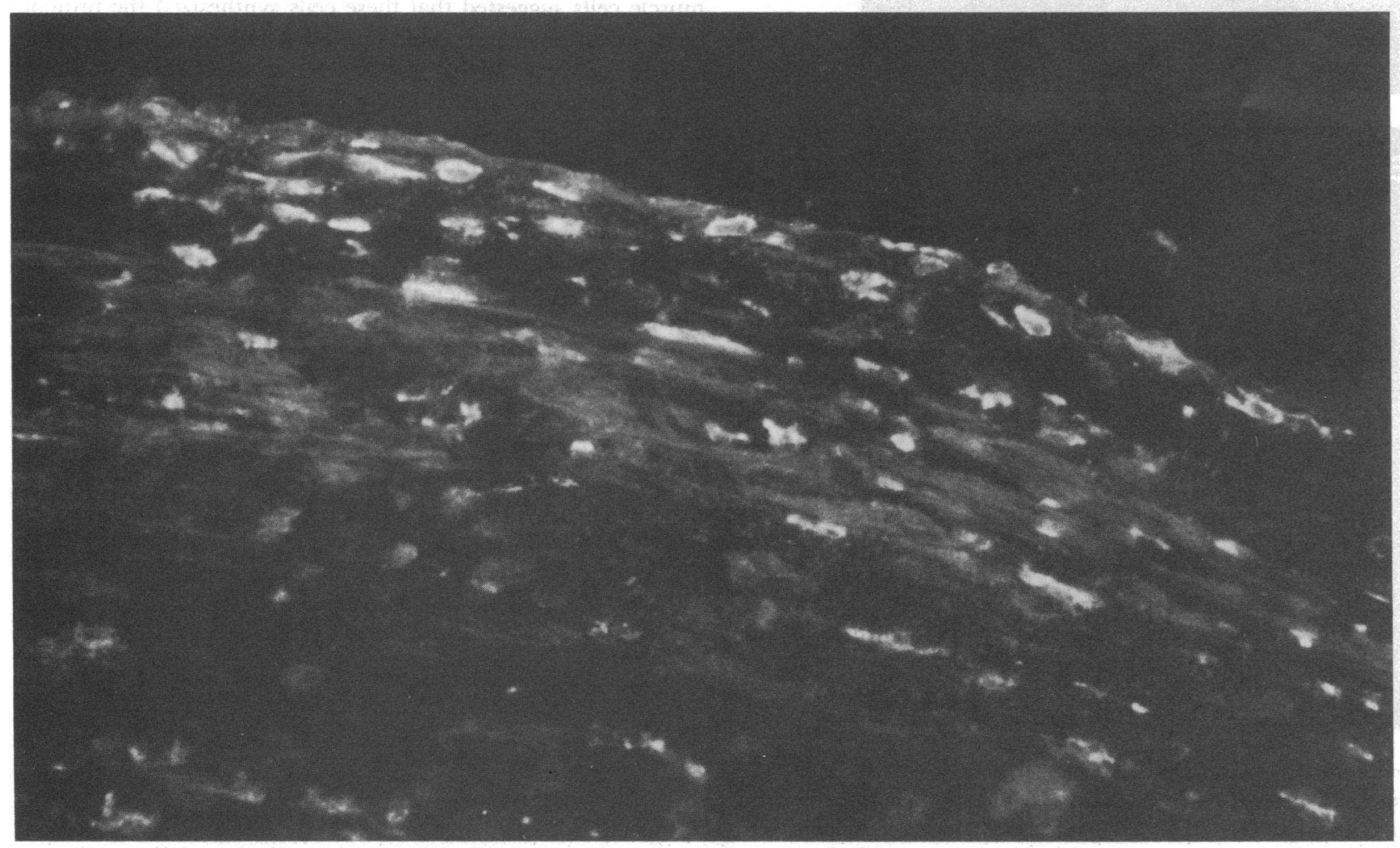

Figure 2. Immunofluorescent detection of HLA-DR antigen in the fibrous cap of an atherosclerotic plaque. Many DR-positive cells are seen (magnification of 1,000). 
Table I. Immunoreactive Cells in Sections of Arterial Tissues*

\begin{tabular}{lllll}
\hline Tissue & OKIa I $^{+}$ & Leu-M3 & Leu-4 & pan-B \\
\hline $\begin{array}{l}\text { Carotid plaque (biopsy) } \\
\text { Intima surrounding }\end{array}$ & $69 \pm 16$ & $29 \pm 10$ & $11 \pm 6$ & $1 \pm 1$ \\
$\quad \begin{array}{l}\text { carotid plaque } \\
\text { (biopsy) }\end{array}$ & $37 \pm 12$ & $8 \pm 4$ & $4 \pm 3$ & 0 \\
$\begin{array}{l}\text { Carotid plaque } \\
\quad \text { (autopsy) }\end{array}$ & 73 & NS & NS & NS \\
$\begin{array}{l}\text { Nonatherosclerotic } \\
\text { carotid intima } \\
\quad \text { (autopsy) }\end{array}$ & & & & \\
$\begin{array}{l}\text { Aorta (biopsy) } \\
\text { Uterine artery (biopsy) }\end{array}$ & 7 & NS & NS & NS \\
& 0 & NS & NS & NS \\
\end{tabular}

* Values are given as percent of the total number of cells, mean \pm SD. NS, not studied.
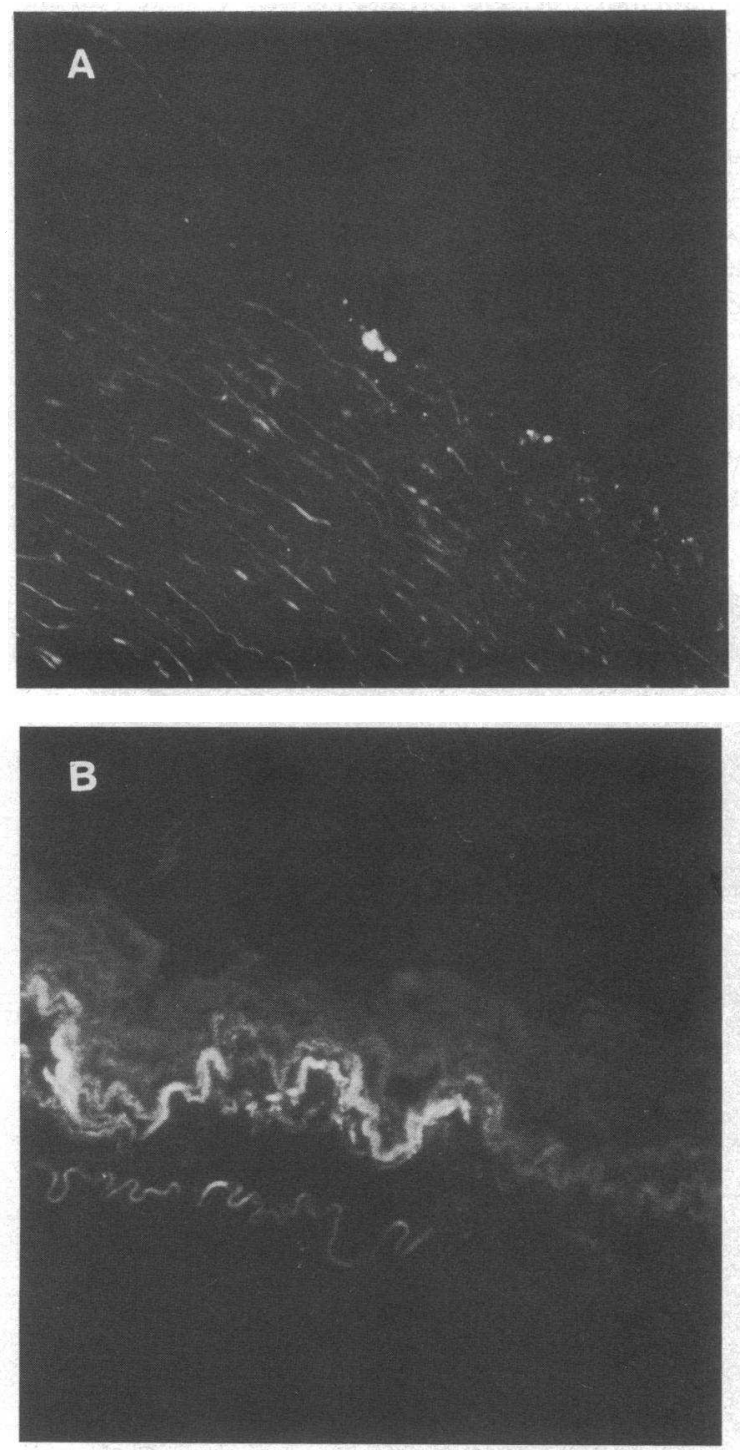

Figure 3. Immunofluorescent detection of HLA-DR antigen in nonatherosclerotic arterial tissue. $(A)$ Base of aorta, removed during coronary bypass surgery. Two DR-positive cells are seen (magnification of 300$)$. (B) Normal uterine artery, which does not contain any DR-positive cells, only a yellow autofluorescence of elastin (magnification of 600 ).
Table II. Distribution of Fc Receptors and DR

Reactivity among Cells Isolated From Plaques*

\begin{tabular}{lrcc}
\hline DR reactivity & FcR $^{+}$ & FcR $^{-}$ & Total \\
\hline OKIal $^{+}$ & 24 & 36 & 60 \\
OKIal $^{-}$ & 6 & 34 & 40 \\
Total & 30 & 70 & 100 \\
\hline
\end{tabular}

* Values are given as percent of the total number of cells, means of two different experiments. FcR, Fc-receptor-positive cells by rosetting test.

To identify the nonleukocytic DR-positive cells, we used double-staining immunofluorescence. Biotin-avidin-FITC staining of HLA-DR was combined with staining of other proteins with polyclonal rabbit antibodies and rhodaminelabeled anti-rabbit IgG. In this way, endothelial cells were identified by rabbit-anti-Factor VIII, and none of these cells were DR-positive. Smooth muscle cells, the other major cell type of arteries, can be identified with antibodies to intermediate filament proteins. Most vascular smooth muscle cells contain vimentin-type intermediate filaments, but a fraction of the cells express desmin together with or instead of vimentin (43). Desmin-type filaments are specific for muscle cells and have not been observed in other cell types (23-25, 32, 33, 44, 45). Antibodies to desmin were therefore used as markers for smooth muscle cells. Double-staining experiments using rabbitanti-desmin and OKIal revealed that $26 \pm 6 \%$ (mean \pm SD) of the DR-positive cells in the plaque contained desmin (Fig. 4). In contrast, there were no DR-positive, desmin-containing cells in the intima surrounding the plaque.

The cytoplasmic distribution of HLA-DR in the smooth muscle cells suggested that these cells synthesized the protein, but it could not be excluded that HLA-DR produced by other cells in the tissue might have adhered to the surface of muscle cells. A series of experiments was performed on isolated cells to answer this question (Fig. 5). First, isolated plaque cells were treated with EDTA under low ionic strength. This removes extrinsic proteins from the plasma membrane (38) but did not reduce the number of DR-positive cells. This number could, however, be reduced drastically by trypsin treatment (Fig. 5). When the cells were allowed to recover for $3 \mathrm{~h}$ after trypsinization, a large proportion of them regained DR-expression (Fig. 5). $3 \mathrm{~h}$ after trypsin treatment, $53.7 \%$ of the DR-positive cells were also desmin-positive in doublestaining immunofluorescence. Taken together, these data show that the HLA-DR reactive antigen is actively expressed as an integral membrane protein of a large proportion of plaque cells, many of which are smooth muscle cells.

Table III. Distribution of E Receptors and DR Reactivity among Isolated Cells of the Plaque*

\begin{tabular}{lllc}
\hline DR reactivity & $\mathrm{E}^{+}$ & $\mathrm{E}^{-}$ & Total \\
\hline OKJal $^{+}$ & 2 & 58 & 60 \\
OKIal $^{-}$ & 3 & 37 & 40 \\
Total & 5 & 95 & 100 \\
\hline
\end{tabular}

* Values given as percent of total cells, means of two different experiments. 

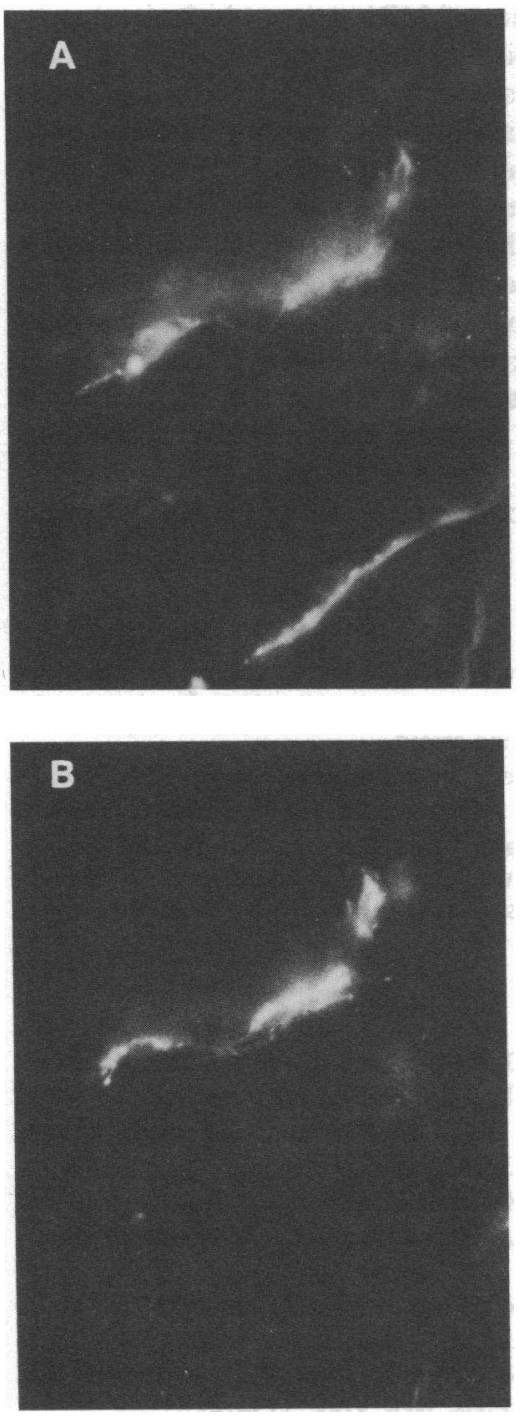

Figure 4. Double-staining with rabbit-anti-desmin $(A)$ and OKIa1 $(B)$ demonstrates HLA-DR expression on a desmin-positive smooth muscle cell in a carotid plaque (magnification of 1,900).

To identify the polypeptide in the plaque which reacted with the anti-HLA-DR antibody, we subjected extracts of homogenized plaques to SDS-polyacrylamide electrophoresis, followed by electroblotting and incubation with OKIa1. The antibody reacted with a polypeptide of $\sim 28,000 \mathrm{Mr}$, corresponding to the beta chain of the HLA-DR protein $(27,46)$ (Fig. 6). The alpha chain of HLA-DR was expressed by the

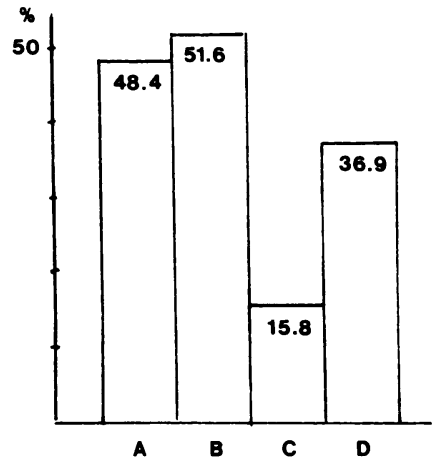

Figure 5. DR reactivity among isolated plaque cells. Values are given as $\mathrm{DR}^{+}$cells in percent of total cells. A, untreated cells; B, cells treated with EDTA in low ionic strength buffer, C, cells immediately after trypsinization; $\mathrm{D}$, trypsintreated cells after $3 \mathrm{~h}$ recovery.
Figure 6. Identification of HLA-DR polypeptide in an atherosclerotic plaque by western blot. The left lane shows the polypeptide composition of the plaque by SDS-polyacrylamide electrophoresis and Coomassie Blue staining. To the right, the anti-HLA-DR antibody OKIal stains a band of $\sim 28,000 \mathrm{Mr}$, corresponding to the beta chain of HLA-DR, on a nitrocellulose paper to which the polypeptides were transferred. Arrows to the left correspond to the position of relative molecular weight markers $(94,000,67,000$, $43,000,30,000$, and 21,100 $M r$, respectively).

same cells, according to immunofluorescent experiments. OKIal and the rat monoclonal YE2.36 (28), which selectively binds to the alpha chain of HLA-DR in immunoblotting tests (Dr. Ian McConnell, University of Edinburgh, personal communication), stained the same number of cells in serial sections of the plaques (Table IV). Taken together, this indicates that the antigen in the plaque reacting with OKIal was HLA-DR, and not a cross-reacting protein.

\section{Discussion}

The characteristics of the cell type or cell types that form the atherosclerotic plaque has remained one of the most enigmatic in cardiovascular research. The vascular smooth muscle cell has the capacity to proliferate and form the fibrotic intimal thickening, which is an important part of the plaque (47). One would, however, have to postulate that it can change its phenotype significantly to explain many other characteristics of the plaque as a tissue, such as intracellular accumulation of cholesterol (48). It has therefore been suggested that the macrophage is a quantitatively important component of the plaque, alone or together with the smooth muscle cell $(49,50)$.

In this study, we show that smooth muscle cells can acquire one of the characteristic features of macrophages, namely the expression of class II transplantation antigen. Our data indicate that approximately two-thirds of the cells of the atherosclerotic plaque of the human carotid artery express HLA-DR antigen, and they suggest that many of these cells are smooth muscle cells. The dramatic increase in the frequency of DR-positive cells in atherosclerosis suggests that the expression of HLA-

Table IV. Expression of the Alpha and Beta Chain of HLA-DR in Sections of Plaques

\begin{tabular}{ll}
\hline Antibody & Positive cells \\
\hline OKIaI & $49.4 \pm 6.8$ \\
YE2.36 & $48.9 \pm 7.1$
\end{tabular}

Number of cells stained by OKIaI (directed against beta) and YE2.36 (anti-alpha) in corresponding regions of serial sections. Means (percent of total number of cells) $\pm \mathrm{SE}, n=12$. Difference is not signifcant (Student's $t$ test). 
DR on smooth muscle cells is linked to the development of the disease.

The detection of smooth muscle cells was based on the expression of the muscle-specific intermediate filament protein, desmin, in DR-positive cells. An alternative explanation to our results would therefore be that DR-positive cells such as macrophages might have started to produce desmin. This latter explanation is, however, very unlikely in view of the fact that while there are many examples in pathological conditions of DR expression by cells that are not normally involved in the immune system (e.g., 11, 14, 17, 19, 21), expression of desmin by nonmuscle cells has never been observed, even under pathological conditions or in cell culture (23-25, $32,33)$.

Our conclusion is also supported by a comparison of the frequency of DR-positive cells with the frequencies of cells positive for other cell surface markers. Many of the cells of the monopoietic and lymphopoietic cell lineages are known to be DR-positive $(2,4)$. Quantitative evaluation of such cells with cell surface markers such as monoclonal antibodies and with receptor assays suggested that less than half of the cells in the plaques were derived from these lineages. In contrast, two-thirds of the cells of the plaques were DR-positive, implicating that many of the DR-positive cells were derived not from the blood but from the intrinsic cells of the vessel wall. The only marker for vascular cells that codistributed with HLA-DR was desmin, which points to a smooth muscle origin of these DR-positive cells. Almost one-third of the DR-positive cells of the plaque contained desmin. The remaining fraction of DR-positive cells was positive neither for desmin nor for the hematopoietic or lymphopoietic cell markers. Many cells in this category were probably also smooth muscle cells, since a large proportion of arterial smooth muscle cells contain vimentin but not desmin in their intermediate filaments (45). Thus, while desmin can be used as a marker for muscle cells, the absence of desmin does not rule out a muscular origin of a cell. Vimentin, on the other hand, was present in practically all cells in the plaque, but is not specific for vascular cells, since all kinds of mesenchymal cells, including those of the blood, contain vimentin-type intermediate filaments $(24,25)$.

As mentioned above, HLA-DR and related class II antigens (Ia antigens) in other species are expressed in immunocompetent cells such as monocytes, macrophages, B cells, and certain $\mathrm{T}$ cells $(2,4)$. They may, however, also be expressed in several epithelial cells $(8,9,13-17,19,20,22,51)$ and endothelial cells $(5,6,10-12)$. Cultured vascular endothelium starts to express HLA-DR when stimulated by lectins or immune interferon (10-12). This shows that the expression of class II antigens may be subjected to regulation. It is now important to identify the stimuli that induce HLA-DR expression on smooth muscle cells, and to determine which of these are active in the arterial intima during the development of atherosclerosis.

The only known function of class II antigens is to participate in the recognition of foreign antigens by $T$ cells $(2,4)$. This reaction is followed by clonal proliferation of specific $\mathrm{T}$ cells (2). This proliferation is probably induced by two growth regulators; interleukin 1, which is produced by the macrophage, and the T cell product interleukin 2 (2). In analogy, "aberrant" expression of Ia antigens by other cells might be related to antigen presentation and/or growth stimulation. Data from studies of human umbilical vein endothelium suggest that these cells can substitute for macrophages as antigen-presenting cells (5). In recent studies of MRL mice, which develop an inherited autoimmune disease, Moyer and Reinisch (52) have shown that smooth muscle cells may express Ia antigen in vasculitis, and probably also present autoantigen(s) to $T$ cells. One could speculate that this might also be the role of the HLA-DR positive smooth muscle cells of the atherosclerotic plaque. Alternatively, the expression of HLA-DR antigen might indicate that other macrophage-like features may be acquired by the smooth muscle cell, such as phagocytosis, receptor-mediated endocytosis of negatively charged proteins, and release of growth factors. A third possibility is that the expression of HLA-DR on these cells is without functional significance, and merely reflects a disturbance in the control of gene expression in smooth muscle cells of the atherosclerotic plaque.

\section{Acknowledgments}

We are indebted to Dr. Kerstin Boström and Dr. Sören Björkerud for giving us access to autopsy material and to Dr. Lars-Åke Nilsson for supplying reagents for rosetting assays.

This work was supported by grants from the Swedish Medical Research Council (projects 6816 and 4531), the Swedish National Association against Heart and Chest Diseases, the Swedish Society of Medical Sciences, Magnus Bergvall's Foundation, the University of Göteborg, and the Swiss National Science Foundation (project $3.178-0.82)$.

\section{References}

1. Peterson, P. A., and O. Kämpe. 1981. Are the classic transplantation antigens primitive cell surface antibodies? In Current Trends in Histocompatibility, Vol. 1. R. A. Reisfeld and S. Ferrone, editors. Plenum Press, New York. 437-452.

2. Palacios, R. 1982. Mechanism of $T$ cell activation: role and functional relationship of HLA-DR antigens and interleukins. Immunol. Rev. 63:73-110.

3. Thorsby, E., B. Bergholtz, and H. Nousiainen. 1981. Self-HLAD-region products restrict human T-lymphocyte activation by antigen. In Current Trends in Histocompatibility, Vol. 2. R. A. Reisfeld and S. Ferrone, editors. Plenum Press, New York. 113-141.

4. Niederhuber, J. E. 1978. The role of I region gene products in macrophage-T-lymphocyte interaction. Immunol. Rev. 40:28-52.

5. Hirschberg, H., O. J. Berg, and E. Thorsby. 1980: Antigenpresenting properties of human vascular endothelial cells. J. Exp. Med. 152:249-255.

6. Hirschberg, H., L. R. Braathen, and E. Thorsby. 1982. Antigen presentation by vascular endothelial cells and epidermal Langerhans cells: the role of HLA-DR. Immunol. Rev. 66:57-77.

7. Klareskog, L., U. Malmnäs-Tjernlund, U. Forsum, and P. A. Peterson. 1977. Epidermal Langerhans cells express Ia-antigens. Nature (Lond.). 268:248-250.

8. Koyama, K., T. Fukunishi, M. Barcos, N. Tanigaki, and D. Pressman. 1979. Human Ia-like antigens in non-lymphoid organs. Immunology. 38:333-341.

9. Natali, P. G., C. de Martino, V. Quaranta, M. R. Nicotra, F. Frezza, M. A. Pellegrino, and S. Ferrone. 1981. Expression of Ia-like antigens in normal human non-lymphoid tissues. Transplantation (Baltimore). 31:75-78.

10. Pober, J. S., and M. A. Gimbrone Jr. 1982. Expression of Ialike antigens by human vascular endothelial cells is inducible in vitro: demonstration by monoclonal antibody binding and immunoprecipitation. Proc. Natl. Acad. Sci. USA. 79:6641-6645.

11. Pober, J. S., T. Collins, M. A. Gimbrone, Jr., R. S. Cotran, J. D. Gitlin, W. Fiers, C. Clayberger, A. M. Krensky, S. J. Burakoff, and C. S. Reiss. 1983. Lymphocytes recognize human vascular endothelial and dermal fibroblast Ia antigens induced by recombinant immune interferon. Nature (Lond.). 305:726-729.

12. Pober, J. S., M. A. Gimbrone, Jr., R. S. Cotran, C. S. Reiss, 
S. J. Burakoff, W. Fiers, and K. A. Ault. 1983. Ia expression by vascular endothelium is inducible by activated $\mathrm{T}$ cells and by human interferon. J. Exp. Med. 157:1339-1354.

13. Forsum, U., L. Klareskog, and P. A. Peterson. 1979. Distribution of Ia-antigen-like molecules on non-lymphoid tissues. Scand. J. Immunol. 9:343-349.

14. Hanafusa, T., L. Chiovato, D. Doniach, R. Pujol-Borrell, R. C. G. Russell, and G. F. Bottazzo. 1983. Aberrant expression of HLA-DR antigen on thyrocytes in Grave's disease: relevance for autoimmunity. Lancet. II:1111-1115.

15. Hjelm, E., U. Forsum, and L. Klareskog. 1982. Anti-Ia-reactive cells in the urinary tract of man, guinea pig, rat and mouse. Scand. $J$. Immunol. 16:531-538.

16. Klareskog, L., U. Forsum, U. Malmnäs-Tjernlund, L. Rask, and P. A. Peterson. 1979. Expression of Ia-antigen-like molecules on cells in the corneal epithelium. Invest. Ophthalmol. Visual Sci. 18: 310-313.

17. Klareskog, L., U. Forsum, and P. A. Peterson. 1980. Hormonal regulation of the expression of Ia antigens on mammary gland epithelium. Eur. J. Immunol. 10:958-967.

18. Klein, J., and V. Hauptfeld. 1976. Ia antigens: their serology, molecular relationships and their role in allograft rejections. Transplant. Rev. 30:83-89.

19. Rognum, T. O., P. Brandtzaeg, and E. Thorsby. 1983. Is heterogenous expression of HLA-DR antigens and CEA along with DNA-profile variations evidence of phenotypic instability and clonal proliferation in human large bowel carcinoma? Br. J. Cancer. 48:543551.

20. Scott, H., B. G. Solheim, P. Brandtzaeg, and E. Thorsby. 1980. HLA-DR-like antigens in the epithelium of the human small intestine. Scand. J. Immunol. 12:77-82.

21. Wilson, B. S., F. Indiveri, M. A. Pellegrino, and S. Ferrone. 1979. DR(Ia-like) antigens on human melanoma cells. Serological detection and immunochemical characterization. J. Exp. Med. 149: 658-668.

22. Barclay, A. N., and D. W. Mason. 1983: Graft rejection and Ia antigens-paradox resolved? Nature (Lond.). 303:382-383.

23. Lazarides, E. 1980. Intermediate filaments as mechanical integrators of cellular space. Nature (Lond.). 283:249-256.

24. Osborn, M., and K. Weber. 1982. Intermediate filaments: celltype-specific markers in differentiation and pathology. Cell. 31: 303-306.

25. Rungger-Brändle, E., and G. Gabbiani. 1983. The role of cytoskeletal and cytocontractile elements in pathologic processes. Am. J. Pathol. 110:359-392.

26. Nadler, L. M., P. Stashenko, R. Hardy, J. M. Pesando, E. J. Yunis, and S. F. Schlossman. 1981. Monoclonal antibodies defining serologically distinct HLA-D/DR related la-like antigens in man. Hum. Immunol. 1:77-90.

27. Reinherz, E. L., P. C. Kung, J. M. Pesando, J. Ritz, G. Goldstein, and S. F. Schlossman. 1979. Ia determinants on human Tcell subsets defined by monoclonal antibody. Activation stimuli required for expression. J. Exp. Med. 150:1472-1482.

28. Brickell, P. M., N. E. Richardson, I. McConnell, and H. A. Feinstein. 1983. Distinct populations of class II molecules identified by monoclonal antibodies. Clin. Exp. Immunol. 54:117-126.

29. Ledbetter, J. A., R. L. Evans, M. Lipinski, C. CunninghamRundles, R. A. Good, and L. A. Herzenberg. 1981. Evolutionary conservation of surface molecules that distinguish T-lymphocyte helper/ inducer and T-cytotoxic/suppressor subpopulations in mouse and man. J. Exp. Med. 153:310-323.

30. Dimitriu-Bona, A., G. R. Burmester, S. J. Waters, and R. J. Winchester. 1983. Human mononuclear phagocyte differentiation antigens. I. Patterns of antigenic expression on the surface of human monocytes and macrophages defined by monoclonal antibodies. $J$. Immunol. 130:145-152.

31. Hansson, G. K., G. A. Starkebaum, E. P. Benditt, and S. M. Schwartz. 1984. Fc-mediated binding of IgG to vimentin-type intermediate filaments in vascular endothelial cells. Proc. Natl. Acad. Sci. USA. 81:3103-3107.
32. Gabbiani, G., E. Rungger-Brändle, C. de Chastonay, and W. W. Franke. 1982. Vimentin-containing smooth muscle cells in aortic intimal thickenings after endothelial injury. Lab. Invest. 47:265269.

33. Kocher, O., O. Skalli, W. S. Bloom, and G. Gabbiani. 1984. Cytoskeleton of rat aortic smooth muscle cells. Normal conditions and experimental intimal thickening. Lab. Invest. 50:645-651.

34. Hansson, G. K., T. Björnheden, A. Bylock, and G. Bondjers. 1981. Fc-dependent binding of monocytes to areas with endothelial injury in the rabbit aorta. Exp. Mol. Path. 34:264-280.

35. Haley, N. J., H. Shio, and S. Fowler. 1977. Characterization of lipid-laden aortic cells from cholesterol-fed rabbits. I. Resolution of aortic cell populations by metrizamide density gradient centrifugation. Lab. Invest. 37:287-296.

36. Bianco, D., R. Patrick, and V. Nussenzweig. 1970. A population of lymphocytes bearing a membrane receptor for antigen-antibodycomplement complexes. J. Exp. Med. 132:702-707.

37. Kaplan, E., and C. Clark. 1974. Improved rosetting assay for detection of human T-lymphocytes. J. Immunol. Methods. 5:131-137.

38. Marchesi, V. T., and E. Steers. 1968. Selective solubilization of a protein component of the red cell membrane. Science (Wash. DC). 159:203-204.

39. Laemmli, U. K. 1970. Cleavage of structural proteins during the assembly of the head of bacteriophage T4. Nature (Lond.). 227: 680-685.

40. Towbin, H., T. Staehelin, and J. Gordon. 1979. Electrophoretic transfer of proteins from polyacrylamide gels to nitrocellulose sheets: procedure and some applications. Proc. Natl. Acad. Sci. USA. 76: $4350-4354$.

41. Huber, H., M. J. Polley, W. P. Linscott, H. H. Fudenberg, and H. J. Müller-Eberhard. 1968. Human monocytes: distinct receptor sites for the third component of complement and for immunoglobulin G. Science (Wash. DC). 162:1281-1286.

42. Parish, C. R. 1975. Separation and functional analysis of subpopulations of lymphocytes bearing complement and Fc-receptors. Transplant. Rev. 25:98-106.

43. Quinlan, R. A., and W. W. Franke. 1982. Heteropolymer filaments of vimentin and desmin in vascular smooth muscle tissue and cultured baby hamster kidney cells demonstrated by chemical cross linking. Proc. Natl. Acad. Sci. USA. 79:3452-3456.

44. Lazarides, E., and B. D. Hubbard. 1976. Immunological characterization of the subunit of the $100 \AA$ filaments from muscle cells. Proc. Natl. Acad. Sci. USA. 73:4344-4348.

45. Schmid, E., M. Osborn, E. Rungger-Brändle, G. Gabbiani, K. Weber, and W. W. Franke. 1982. Distribution of vimentin and desmin filaments in smooth muscle tissue of mammalian and avian aorta. Exp. Cell Res. 137:329-340.

46. Klareskog, L., L. Trägårdh, L. Rask, and P. A. Petterson. 1979. Isolation and characterization of detergent-solubilized human HLADR transplantation antigens. Biochemistry. 18:1481-1489.

47. Ross, R., and J. A. Glomset. 1973. Atherosclerosis and the arterial smooth muscle cell. Science (Wash. DC). 180:1332-1339.

48. Campbell, J. H., L. Popadynec, P. J. Nestel, and G. R. Campbell. 1983. Lipid accumulation in arterial smooth muscle cells. Influence of phenotype. Atherosclerosis. 47:279-295.

49. Fowler, S., H. Shio, and N. J. Haley. 1979. Characterization of lipid-laden aortic cells from cholesterol-fed rabbits. IV. Investigation of macrophage-like properties of aortic cell populations. Lab. Invest. 41:372-378.

50. Schaffner, T., K. Taylor, E. J. Bartucci, K. Fischer-Dzoga, J. H. Beeson, S. Glagov, and R. W. Wissler. 1980. Arterial foam cells with distinctive immunomorphologic and histochemical features of macrophages. Am. J. Pathol. 100:57-78.

51. Barclay, A. N., and D. W. Mason. 1982. Induction of Ia antigen in rat epidermal cells and gut epithelium by immunological stimuli. J. Exp. Med. 156:1665-1676.

52. Moyer, C. F., and C. L. Reinisch. 1984. Ia expression and antigen presentation by vascular smooth muscle cells. Fed. Proc. 43: 972a. (Abstr.) 